\title{
Stroop test software. The Tastiva proposal
}

\section{Software para pruebas Stroop. La propuesta de Tastiva}

\author{
María Claudia Scurtu ${ }^{1}$, Vicente Manzano-Arrondo ${ }^{2}$ y Juan Francisco Rodríguez Testal ${ }^{1}$ \\ ${ }^{1}$ Departamento de Personalidad, Evaluación y Tratamiento Psicológicos, Universidad de Sevilla, España. \\ ${ }^{2}$ Departamento de Psicología Experimental, Universidad de Sevilla, España.
}

Available online 31 August 2016

\begin{abstract}
There has been a great deal of research on emotional information processing within the field of clinical psychology. Many tests have been developed and the emotional Stroop test is one of the most used. However, some versions of the Stroop test have methodological issues when used to study word-colour interferences, especially when the words are emotionally charged. We present a computer-assisted version of the emotional Stroop test called Tastiva, which is highly versatile, useful, and accessible, in addition to being easy to use and widely applicable. The Tastiva software and User Manual is available on the University of Seville website: http://grupo.us.es/recursos/Tastiva/index.htm. We also present a case study using neutral and sexual content words, in which the program calculates the word exposure time by analysing the behaviour of the respondent. One of its novel contributions is the graphic presentation of measures: response time, errors, and non-response to stimuli.
\end{abstract}

Key Words: Classic Stroop; Emotional Stroop; Computer-assisted Stroop; Tastiva.

La investigación sobre el procesamiento de la información emocional ha ocupado numerosas páginas en psicología clínica y se han empleado muchas pruebas a lo largo del tiempo, siendo la tarea Stroop emocional una de las más utilizadas. Para estudiar la interferencia color-palabra, sobre todo las que tienen carga emocional, las múltiples versiones de la prueba Stroop no siempre garantizan una corrección metodológica. Nuestro objetivo es la propuesta de una versión Stroop emocional por ordenador llamada Tastiva, de gran versatilidad, utilidad y accesibilidad además de su fácil y amplia aplicabilidad. El software en sí de Tastiva junto con el Manual de usuario están disponibles en la página web de la Universidad de Sevilla: http://grupo.us.es/recursos/Tastiva/index.htm. A la vez presentamos un caso práctico, utilizando palabras neutras y palabras de contenido sexual, en donde el propio programa calcula el tiempo de exposición de las palabras, analizando el comportamiento del participante, junto con otra aportación novedosa a la prueba Stroop: la representación gráfica de las medidas tiempo de respuesta, errores y no-respuesta al estímulo.

Palabras Clave: Stroop Clásico; Stroop Emocional; Stroop por Ordenador, Tastiva.

Correspondence concerning this article should be addressed to: Vicente Manzano Arrondo. Departamento de Psicología Experimental; Universidad de Sevilla, c/ Camilo José Cela s/n 41018, Sevilla, España/Spain; Phone: 954557646; Fax: 954558436; E-mail: vmanzano@us.es. Co-authors' e-mails: María Claudia Scurtu: clauditza_psi@yahoo.com; Juan Francisco Rodríguez Testal: testal@us.es 
In order to solve some preliminary concerns about interference in information processing, Stroop (1935) designed an experimental test in which participants must indicate which color is written on each of the words from a list. What makes this software unique is that the words are names of colors and there is no consistency between the meaning of the word and the ink in which it is written. For example, the blue word is written in red ink, and the participant must indicate "red", not "blue". Stroop noted that the reading of the meaning of words was fluid and did not interfere with the color in which they were written. However, reading color seemed to significantly be affected by the meaning of the word, resulting in a slower execution of the task. Over time, the test was not only widely replicated, but also the subject of numerous variations, strengthening its universal character and verifying that the Stroop effect is not reduced by practice (MacLeod, 1991). In its classic or variations version, Stroop test was used to the study of various psychological processes such as memory, language skills, perception, and particularly in detecting individual differences or brain dysfunctions that affect attention (Armengol \& Cavanaugh, 2003; Mackin, 2002; Reeve \& Schandler, 2001, Sabri, Melara \& Algom, 2001) or inhibition of automatic responses, features linked to frontal lobe capacity and specificity (Milham, Banich \& Barad, 2003).

A relevant task to the clinical setting constitutes the emotional Stroop (Pérez \& Fox, 2003), in which the increase of response time is due to involuntary processing of the emotional content of the words (Williams, Mathews \& McLeod, 1996). The person turns his attention more or less automatically to the meaning of the words delaying the execution of the main task, which is the color naming of the word. It is about a deviation of attention, results of the emotional or activator character of the word which disrupts the normal course of color processing word. According to MacLeod \& MacDonald (2000), attention allows an individual to respond selectively to different environmental events, which can be an emotionally attentional bias towards stimuli relevant to the individual. This means that attention directed towards the emotional content of the stimulus make subjects take longer to identify the color which is written the word compared to other neutral content word. Originally, the emotional Stroop test was designed to better the understanding of psychological processes that regulate the behavior of people, in particular cognitive and emotional processing of emotional words (Pérez \& Fox, 2003). The evidence collected by Williams, Mathews, \& McLeod (1996), support the hypothesis that Stroop interference is the effect of a disposition, which is a condition that has been constituted over time. They define the effect of interference in the emotional Stroop as deep rooted past occurrences that the subject ruminates frequently and intensely about things which have worried and affected him/ her. It has also been observed that personal history influences this type of interference (Mathews \& Klugg, 1993; Mathews \& MacLeod, 2005), and this happens even when writing all the words in the same color (Compton et al., 2003).
The emotional Stroop test has proven its usefulness to study the processing of emotional information in various kinds of clinical conditions: to detect cognitive deficits or selective processing of information, or to check the effectiveness of a treatment applied: alexithymia (Mueller, Alpers \& Reim, 2006; Wingenfeld et al., 2011); schizophrenia (Henik \& Salo, 2004; Krabbendam, O’Daly, Morley, van Os, Murray \& Shergill, 2009; Woodward, Ruff, Thorton, Moritz \& Liddle, 2003); bulimia nervosa (Camacho-Ruíz, Mancilla-Díaz, Escoto-Ponce De León \& Yáñez-Tellez, 2009; Lokken, 2002); anorexia nervosa (Dobson \& Dozois, 2004); positive schizotypy (Kerns, 2005; Kerns \& Berenbaum, 2000); trait and state anxiety (Mercado, 2004); brain damage (Pujol et al., 2001), ADHD (Savitz \& Jansen, 2003), Alzheimer's disease (Bondi et al., 2002), depression (Epp, Dobson, Dozois \& Frewen, 2012; Fallon, 2013); chronic pain (Anderson \& Haldrup, 2003; Roelofs, Peters, Zeegers \& Vlaeyen, 2002), and panic disorder (Quero, Baños $\&$ Botella, 2000). The implicit nature of some procedures about complex cognitive processes could allow greater reliability and validity in the evaluation of certain psychotic indicators (SenínCalderón, Rodríguez-Testal \& Perona-Garcelán, 2014), demonstrating its cost efficiency, i.e. less staff but better prepared, and savings on materials; the emotional Stroop test, therefore, represents an automatic task that doesn't require special intellectual or manual execution abilities.

\section{The computer Stroop}

Processing tasks words and interaction between people and computers have been increasing over the years (Taylor \& Fragopanagos, 2005). In order to have more control of the measurement in time response and stimulus presentation, (Cordova, Karnikowski, Pandossio \& Nóbrega, 2008), the original paper version of the Stroop task was adapted to the computer and the first computerized implementation is due to Richards \& Millowood (1989). In these programs the participants respond to the corresponding color of words using the keyboard and the latency times are recorded in the answers and the number of hits and errors. In its original paper and pencil version, the information is also in visual format and the response is verbal, that is, each participant says the color that the word is written. This divergence has caused some doubt showing that the interference it is not the same as the computerized version (MartínezSánchez \& Marín-Serrano, 1997). However, various tests demonstrate that manual or verbal tasks have no practical effect on the Stroop interference (Rose, Wilsoncroft \& Griffiths, 1980; Virzi \& Egeth, 1985).

Another significant variation between paper and computer versions is how stimuli or words are presented. In paper format, all the words are present and the participant is saying the color of each one, respecting the order accordingly. In the computerized format, you can control the time exposure of each stimulus, and, in fact, words are presented in intervals controlled by the program. Some research (for example Schooler, Neumann, 
Caplan \& Roberts, 1997) indicate that in certain clinical profiles, such as schizophrenia, implementation of computerized task may be lower, not only by the peculiar emotional processing of these patients, but for added difficulties when exposed to words one by one, in a continued time period.

Usually, classic or emotional computerized versions of Stroop were generated ad hoc, that is, to serve for a specific experimental task in a concrete case (see, for example, Acosta \& Lupiáñez, 2002; Baños, Quero \& Botella, 2005, Calleja \& Hernández-Pozo, 2009; Dresler, Mériau, Heekeren \& van der Meer, 2009; Fuentes et al., 2003; Quero, Baños \& Botella, 2000). Therefore, the generated software does not require an elaborate design and scientific publications do not offer a detailed description of the task, so some relevant aspects are beyond the possibility of constructive criticism. In these types of tasks, the words appear one by one, on a homogeneous background screen; accompanied by a system specification of colors; every word is present while the response is not issued; answers are given by keystroke; and performance time data are stored in a single file for each participant and then processed with a specific data analysis program. As in the case specified in Dresler, Mériau, Heekeren \& van der Meer (2009), some programs include an initial block for participants to familiarize themselves with the task.

The ad hoc types are accompanied by two disadvantages of width: firstly, problems of accessibility to specialized software, either through ignorance, lack or cost and secondly, the need for the software to suit the specific requirements for each research. Due to the limited space in scientific publications, the studies using computer Stroop are very parsimonious in details on the functioning of the program. This circumstance means that opportunities for improvement of the software are lost, as in cases where we can have access to alternative hypotheses due to procedural strange variables which publications lack.

This paper provides a solution to both problems: providing specific software for computer Stroop tasks, which is not only accessible but also adaptable.

\section{Tastiva}

The name Tastiva is an acronym for Variable Time Stroop Task. It is a computer program compiled in Pascal, through Borland Delphi IDE and available for Windows environments or emulators from the XP version. Tastiva reads words, colors and features of the process from disk files, presents stimuli on the screen one by one and records different information, enabling further analysis and various research managements.

Basically, three characteristics define its operation: versatility, marginal utilities and accessibility.

\section{Versatility}

The words and their corresponding colors are not implemented in the program code, but read from an external file in text format, which can be drawn from Tastiva or other utilities and includes the ability to insert pauses execution. There is a palette of various colors the researcher could choose to define each word.

Also, there are several possibilities for time management; the procedure time controlled by the participant when the stimuli appears on the screen, hundreds of a second defined by the researcher, which includes not only exposure, but also the time in which the answer is viable without the presence of the word, and the length of blank screen between one word and the next. Additionally, there is the option that Tastiva can calculate the time variably, according to the preliminary tests, ensuring that the task has an equivalent level of difficulty for all participants.

Process. Tastiva controls the exposure in three phases: (1) familiarity with the mechanical task, (2) familiarity with the experimental task, and (3) experimental task in itself. The investigator decides the content of each phase, whether it is reference time for stimuli or not, and how the program manages time from a context file that has a corresponding subprogram or specific utility in Tastiva. The program guides the phases on reading, analyzing and presenting the stimuli until the end of information processing.

\section{Marginal utilities}

Each individual execution generates an output file that can be opened in any word processor. Tastiva also allows individual files to be grouped into one, selecting the information to be included for further analysis. Similarly, each individual file result can be viewed not only as a disk file, but also by using a specific Tastiva graph. The response process is then displayed including the delay spent on each word and the existence of errors, if any. The generated image may be colored, distinguishing emotional content words, using a color pattern defined by the investigator. The program also performs some analysis of inter-phase data. In the Tastiva program it is easy to generate the file of words and colors using a specific function, which guarantees a final readable format using a minimum effort and it is easy to include pauses in execution. Similarly, if the investigator decides that the presentation of the words adapts to its length, the program has an advantage which allows the calculation of time reading.

\section{Accesibility}

Unlike other software that are using stimuli presentation and measure time responses, to other software programs that can only be pre-paid (E-Prime, Chronos, MRI Simulator, Celeritas, etc.), Tastiva is available free of charge. Due to that reason, it does not have any technical support, except for a User Manual available on: http://grupo.us.es/recursos/Tastiva/index. $\underline{\mathrm{htm}}$.

\section{A practical case using emotional Stroop}

To briefly show how the Tastiva program works, we present an example of emotional Stroop using words that have a strong meaning and salience. We used a context of 51 words divided into three phases. In the first phase we used 9 neutral units 
(such as words like sock or bag), when the participant becomes familiar with the computerized task; each word appears on the screen until one of the three buttons with RED, YELLOW and GREEN label are pressed. After pressing the button, the screen returns to black for a split second, before displaying the next word.

The second phase includes 12 neutral words, but which exposure times are calculated by Tastiva, based on previous response times. During this phase, the participant becomes habituated with the experimental task. The third is composed of 30 units, but four of them are words with strong sexual meaning and therefore having a clear emotional impact: bitch (position 25), pussy (33), dick (37) and masturbate (46).

Table 1 shows a specific individual result. The time exposure column shows that the stimulus word is presented differently in the three phases. In the first one, the exposure and response time coincide, because the word remain on the screen while the participant presses the color button. In the second phase, each stimulus was exhibited in a period of time that Tastiva calculates depending on the time response used in the last six exposures, keeping the participant in suspense. In the third phase, the exposure time remains constant, according to calculations made during the previous phase.

Table 1

Individual file results (detail).

\begin{tabular}{|c|c|c|c|c|c|c|c|}
\hline \multicolumn{4}{|c|}{ Stimuli } & \multicolumn{2}{|c|}{ Response } & \multicolumn{2}{|l|}{ Time } \\
\hline Order & Phase & Word & Color & Color & True & Exposure & Response \\
\hline 1 & 1 & sock & 2 & 2 & 1 & 1531 & 1531 \\
\hline 2 & 1 & stars & 1 & 1 & 1 & 1062 & 1062 \\
\hline 3 & 1 & kilogram & 3 & 3 & 1 & 1266 & 1266 \\
\hline \multicolumn{8}{|l|}{$\ldots$} \\
\hline 27 & 2 & acoustic & 3 & 0 & 0 & 220 & 1406 \\
\hline 28 & 3 & linear & 1 & 1 & 1 & 239 & 1219 \\
\hline 29 & 3 & cow & 2 & 2 & 1 & 239 & 1250 \\
\hline \multicolumn{8}{|l|}{$\ldots$} \\
\hline 45 & 3 & particular & 1 & 1 & 1 & 239 & 1344 \\
\hline 46 & 3 & masturbate & 3 & 0 & 0 & 239 & 1500 \\
\hline 47 & 3 & distinct & 2 & 2 & 1 & 239 & 985 \\
\hline 48 & 3 & medium & 3 & 3 & 1 & 239 & 1188 \\
\hline 49 & 3 & figured & 1 & 1 & 1 & 239 & 781 \\
\hline 50 & 3 & blackboard & 2 & 2 & 1 & 239 & 906 \\
\hline 51 & 3 & rustic & 3 & 3 & 1 & 239 & 922 \\
\hline
\end{tabular}

Note: the color 0 expresses no answer. Times exposure and response is given in milliseconds.

By utilizing the graph, it is an easier and more complete way to interpret the participant results. Tastiva allows the use of solid bars (as in Figure 1), hollow rods and lines. The graph answers can be colored by using a color pattern file. In this case, each file is labeled with a number, i.e. 1 for the color black, with four digits 4 (for the color red) in positions corresponding to the taboo words $(25,33,37$ and 46$)$, for a total of 51 digits, separated by a space (applicable in Tastiva software). Figure 1 shows various behaviors of interest: the highest response times are in the experimental phase, by three of the four taboo words. The first word generated very visible results: the response time ran out without the participant pressing a color button (which is represented by a red circle on the base), but make a mistake in the following color word (typical - neutral content, represented by a blue circle at the base), and ran out of response time for the following word (also neutral content, acoustic). These results show the convenience to visually analyze the individual graphs; by including this data into a statistical analysis program it could generate confusion provoked by the emotional word previously viewed by the participant.

Figure 1

Tastiva display for graph presentation of results.

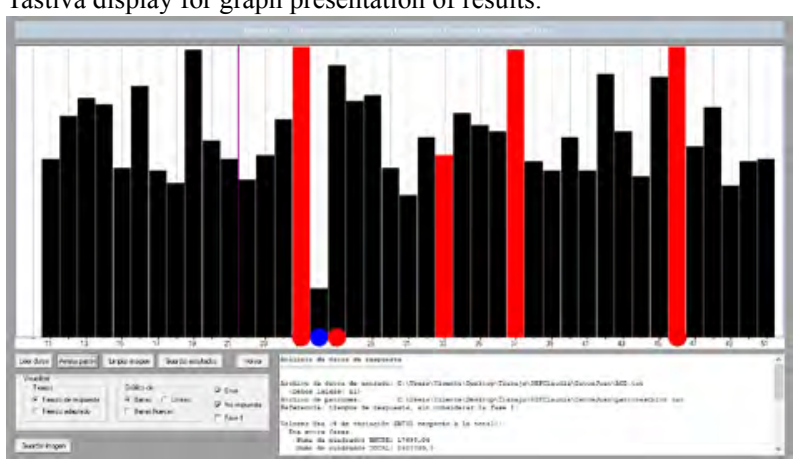

Note: The red bars correspond to the taboo words. The red circles indicate no response, while blue circles indicate wrong answers.

\section{Conclusions and discussion}

Using Stroop tasks, either in its classic or emotional format, allows multiple possibilities for research and practical application, for example, diagnostic or monitoring of an intervention. For these reasons, Stroop has been used in a wide range of investigations.

The time exposure control of the words and the accurate measurement of the answers, are two of the requirements that have supported the implementation of the Stroop test by computer programs. However, these programs are designed to suit each type of research, without the use of a well-known and accessible software which could assess the methodological guarantees of such applications in depth.

With the aim of providing a solution to this, we created Tastiva, a specific software for Stroop tasks, free of charge, accessible and versatile, that could be adapted to a large variety of investigations using these kinds of programs.

Tastiva has some limitations to consider. On the one hand, it is available only for Windows environments. This drawback is reduced in practice thanks to computer emulators present in other operating systems, as in several Linux distributions. However, emulations are not available in all cases. Another disadvantage which lowers its applicability in some Stroop variants is that Tastiva uses only words. Nothing prevents it from using short sentences rather than simple words which extension should not pass the dimensions of a line on the screen. However, it does not allow images, videos or sounds, elements that can be used in some variations of the classic Stroop task. Finally, it is not possible to anticipate and to meet all the needs 
of practical implementation in the psychological field, which requires the research teams to be very creative. Despite these limitations, Tastiva adapts to a wide range of research projects, allowing an accurate study due to the graph presentation of the results, and providing a benchmark for methodological evaluation on experimental tasks in the psychological field.

\section{References}

1. Acosta, A. \& Lupiáñez, J. (2002). Efectos del priming en la tarea Stroop emocional de nombrar color: ¿modulación automática o estratégica de la respuesta? REME: Revista Electrónica de Motivación y Emoción, 6, 14-15. Recuperado de: http://reme.uji.es/articulos/avillj3021702105/texto. $\underline{\mathrm{html}}$

2. Anderson, G. \& Haldrup, D. (2003). Personalized pain words and Stroop interference in chronic pain patients. European Journal of Pain, 7, 431-438. http://dx.doi. org/10.1016/S1090-3801(03)00002-8

3. Armengol, C. G. \& Cavanaugh, A. (2003). Diferencias en la ejecución de niños con síndrome de estrés post-traumático, trastorno por déficit de atención con hiperactividad y grupo control en tests de atención e inhibición. Revista Española de Neuropsicología, 5, 65-79.

4. Baños, R. M., Quero, S. \& Botella, C. (2005). Sesgos atencionales en la fobia social medidos mediante dos formatos de la tarea Stroop emocional (de tarjetas y computerizado) y papel mediador de distintas variables clínicas. International Journal of Clinical and Health Psychology, 5, 23-42.

5. Bondi, M. W., Serody, A. B., Chan, A. S., Eberson-Shumate, S. C., Delis, D. C., Hansen, L. A. \& Salmon, D. P. (2002). Cognitive and neuropathologic correlates of Stroop color -word test performance in Alzheimer's disease. Neuropsychology, 16, 335-343. http://dx.doi.org/10.1037/08944105.16.3.335

6. Calleja, N. \& Hernández-Pozo, R. (2009). Prueba Stroop computarizada de riesgo tabáquico para adolescentes. Revista Mexicana de Análisis de la Conducta, 35, 91-107. http://dx.doi.org/10.5514/rmac.v35.i2.16110

7. Camacho-Ruíz, E. J., Mancilla-Díaz, J. M., Escoto-Ponce De León, M. C. \& Yáñez-Tellez, M. G. (2009). Diseño y validación de una tarea computarizada tipo Stroop para evaluar sesgos de la atención en bulimia nerviosa. Revista mexicana de análisis de la conducta, 35, 75-89. http:// dx.doi.org/10.5514/rmac.v35.i2.16109

8. Compton, R. J., Banich, M. T., Mohanty, A., Milham, M. P., Herrington, J., Miller, G. A. \& Heller, W. (2003). Paying attention to emotion: an fMRI investigation of cognitive and emotional Stroop tasks. Cognitive, Affective, and Behavioural Neuroscience, 3, 81-96. http://dx.doi.org/10.3758/ CABN.3.2.81

9. Córdova, C., Karnikowski, M. G. O., Pandossio, J. E. \& Nóbrega, O. T. (2008). Caracterização de respostas comportamentais para o teste de Stroop computadorizado - Testinpacs. Neurociências. 4, 75-79.
10. Dobson, K. S. \& Dozois, D. J. (2004). Attentional biases in eating disorders: a meta-analytic review of Stroop performance. Clinical Psychology Review, 23, 1001-1022. http:// dx.doi.org/10.1016/j.cpr.2003.09.004

11. Dresler, Th., Mériau, K., Heekeren, H. R. \& van der Meer, E. (2009). Emotional Stroop task: effect of word arousal and subject anxiety on emotional interference. Psychological Research, 73, 364-371. http://dx.doi.org/10.1007/ $\underline{\text { s00426-008-0154-6 }}$

12. Epp, A. M., Dobson, K. S., Dozois, D. J. \& Frewen, P. A. (2012). A systematic meta-analysis of the Stroop task in depression. Clinical Psychology Review, 32, 316-328. http://dx.doi.org/10.1016/j.cpr.2012.02.005

13. Fallon, E. J. (2013). Where is the emotional Stroop effect in depression? Nova University of Newcastle Research Online. Recuperado de: http://hdl.handle.net/1959.13/1037303.

14. Fuentes, L. J, González, G., Estévez, A. F., Carranza, J. A., Daza, M., Galián, M. D. \& Álvarez, D. (2003). Sensibilidad de algunas pruebas estandarizadas para evaluar el funcionamiento de la atención ejecutiva en niños de siete años. REIPP: Revista Electrónica de Investigación Psicoeducativa y Psicopedagógica, 1. Retrieved from http:// www.investigacion-psicopedagogica.org/revista/new/ContadorArticulo.php?23

15. Henik, A. \& Salo, R. (2004). Schizophrenia and the Stroop Effect. Behavioral and Cognitive Neuroscience Reviews, 3, 42-59. http://dx.doi.org/10.1177/1534582304263252

16. Kerns, J. G. (2005). Positive schizotypy and emotion processing. Journal of Abnormal Psychology, 114, 392-401. http://dx.doi.org/10.1037/0021-843X.114.3.392

17. Kerns, J. G. \& Berenbaum, H. (2000). Aberrant semantic and affective processing in people at risk for psychosis. Journal of Abnormal Psychology, 109, 728-732. http:// dx.doi.org/10.1037//0021-843X.109.4.728

18. Krabbendam, L., O’Daly, O., Morley, L. O., van Os, J., Murray, R. M., \& Shergill, S. S. (2009). Using the Stroop task to investigate the neural correlates of symptom change in schizophrenia. The British Journal of Psychiatry, 194, 373-374. http://dx.doi.org/10.1192/bjp.bp.108.055459

19. Lokken, K. L. (2002). The analysis of selective information processing and neuropsychological functioning in individuals at-risk for eating disorders: the use of a pictorial adaptation to the Stroop paradigm, using print media advertisements. Dissertation Abstracts International: Section B: The Sciences y Engineering, 63, 535.

20. Mackin, R. S. (2002). Investigating neuropsychological correlates of adult attention deficit disorder (ADHD). Dissertation Abstracts International: The Sciences and Engineering, 62, 3383.

21. MacLeod, C. M. (1991). Half a century of research on the Stroop effect: an integrative review. Psychological Bulletin, 109, 163-203. http://dx.doi.org/10.1037/00332909.109.2.163

22. MacLeod, C. M. \& MacDonald, P. A. (2000). Interdimen- 
sional interference in the Stroop effect: uncovering the cognitive and neural anatomy of attention. Trends in Cognitive Sciences, 4, 383-391. http://dx.doi.org/10.1016/S1364$\underline{6613(00) 01530-8}$

23. Martínez-Sánchez, F. \& Marín-Serrano, J. (1997). Influencia del nivel de alexitimia en el procesamiento de estímulos emocionales en una tarea Stroop. Psicothema, 9, 519-527.

24. Mathews, A. M. \& Klugg, F. (1993): "Emotionality and interference with color-namig in anxiety", Behaviour Research and Therapy, 31, 57-62. http://dx.doi. org/10.1016/0005-7967(93)90043-T

25. Mathews, A. M. \& MacLeod, C. M. (2005). Cognitive vulnerability to emotional disorders. Annual Review of Clinical Psychology, 1, 167-195. http://dx.doi.org/10.1146/ annurev.clinpsy.1.102803.143916

26. Mercado, F. (2004). Sesgos atencionales en la ansiedad rasgo y en la ansiedad estado: un estudio electrofisiológico de actividad cerebral. Tesis doctoral. Universidad Autonóma de Madrid, Facultad de Psicología.

27. Milham, M. P., Banich, M. T. \& Barad, V. (2003). Competition for priority in processing increases prefrontal cortex's involvement in top-down: an event-related fMRI study of the Stroop task. Cognitive Brain Research, 17, 212-222. http://dx.doi.org/10.1016/S0926-6410(03)00108-3

28. Mueller, J., Alpers, G.W. \& Reim, N. (2006). Dissociation of rated emotional valence and Stroop interference in observer-rated alexithymia. Journal of Psychosomatic Research, 61, 261-269. http://dx.doi.org/10.1016/j.jpsychores.2006.02.017

29. Pérez, K. \& Fox, N. A. (2003). Individual differences in children's performance during an emotional Stroop task: A behavioural and electrophysiological study. Brain and Cognition, 52, 33-51. http://dx.doi.org/10.1016/S02782626(03)00007-1

30. Pujol, J., Vendrell, P., Deus, J., Junqué, C., Bello, J., MartiVilat, J. L. \& Capdevila, A. (2001). The effect of medial frontal and posterior parietal demyelinating lesions on Stroop interference. NeuroImage, 13, 68-75. http://dx.doi. org/10.1006/nimg.2000.0662

31. Quero, S., Baños, R. M. \& Botella, C. (2000). Sesgos cognitivos en el trastorno de pánico: comparación entre el Stroop computarizada y con tarjetas. Psicothema, 12, 165-170.

32. Reeve, W. V. \& Schandler, S. L. (2001). Frontal lobe functioning in adolescents with attention deficit hyperactivity disorder. Adolescence, 36, 749-765.

33. Richards, A. \& Millwood, B. (1989). Colour-identification of differentially valenced words in anxiety. Cognition and Emotion, 3, 171-176. http://dx.doi. org/10.1080/02699938908408078

34. Roelofs, J., Peters, M. L., Zeegers, M. P. \& Vlaeyen, J. W. (2002). The modified Stroop paradigm as a measure of selective attention towards pain-related stimuli among chronic pain patients: a meta-analysis. European Journal of
Pain, 6, 273-281. http://dx.doi.org/10.1053/eujp.2002.0337 35. Rose, W. T., Wilsoncroft, W. E. \& Griffiths, K. S. (1980). Effects of motor and verbal practice on the Stroop task. Perceptual and Motor Skills, 50, 647-650. http://dx.doi. org/10.2466/pms.1980.50.2.647

36. Sabri, M., Melara, R. D. \& Algom, D. (2001). A confluence of contexts: asymmetric versus global failures of selective attention to Stoop dimensions. Journal of Experimental Psychology: Human Perception and Performance, 27, 515537.

37. Savitz, J. B. \& Jansen, P. (2003). The Stroop Color-Word Interference. Test as an Indicator of ADHD in Poor Readers. Journal of Genetic Psychology, 164, 319-324. http:// dx.doi.org/10.1080/00221320309597986

38. Schooler, C., Neumann, E., Caplan, L. J. \& Roberts, B. R. (1997). A time course analysis of Stroop interference and facilitation: comparing normal individuals and individuals with schizophrenia. Journal of Experimental Psychology, 126, 19-36. http://dx.doi.org/10.1038/376549a0

39. Senín-Calderón, M. C., Rodríguez-Testal, J. F. \& PeronaGarcelán, S. (2014). El pensamiento referencial: aspectos psicopatológicos y del desarrollo. Charleston, SC: CreateSpace Independent Publishing Platform.

40. Stroop, J. R. (1935). Studies on interference in serial verbal reactions, Journal of Experimental Psychology, 18, 643662. http://dx.doi.org/10.1037/0096-3445.121.1.15

41. Taylor, J. G. \& Fragopanagos, N. F. (2005). The interaction of attention and emotion. Neural Networks, 18, 353-359. http://dx.doi.org/10.1016/j.neunet.2005.03.005

42. Virzi, R. A. \& Egeth, H. E. (1985). Toward a translational model of Stroop interference. Memory and Cognition, 13, 304-319. http://dx.doi.org/10.3758/BF03202499

43. Williams, J. M. G., Mathews, A. \& MacLeod, C. (1996). The Emotional Stroop Task and Psychopathology. Psychological Bulletin, 120, 3-24. http://dx.doi.org/10.1037/00332909.120.1.3

44. Wingenfeld, K., Riedesel, K., Petrovic, Z., Philippsen, C., Meyer, B., Rose, M. \& Spitzer, C. (2011). Impact of childhood trauma, alexithymia, dissociation, and emotion suppression on emotional Stroop task. Journal of Psychosomatic Research, 70, 53-58. http://dx.doi.org/10.1016/j. ipsychores.2010.06.003

45. Woodward, T. S., Ruff, C. C., Thornton, A. E., Moritz, S. \& Liddle, P. F. (2003). Methodological considerations regarding the association of Stroop and verbal fluency performance with the symptoms of schizophrenia. Schizophrenia Research, 61, 207-214. http://dx.doi.org/10.1016/S09209964(02)00211-6

Received 22 August 2015 Received in revised form 24 January 2016 Accepted 23 March 2016 